\title{
Study of Bed Load Transport in Code River
}

\section{(Case Study in Yogyakarta Region)}

\author{
Jazaul Ikhsan ${ }^{1}$, Puspastyari Windamukti ${ }^{1}$ \\ ${ }^{1}$ Department of Civil Engineering, Universitas Muhammadiyah Yogyakarta, Indonesia \\ *Corresponding author. Email: jazaul.ikhsan@umy.ac.id
}

\begin{abstract}
Code River is a river located in the Province of Yogyakarta Special Region (DIY) and one of the rivers that divide the city of Yogyakarta. Three regency areas are crossed by the Code River, namely: Sleman Regency, Yogyakarta City and Bantul Regency. The majority of people living around the river utilize the river flow as necessities such as toilets (bath, wash and toilet), irrigation for agriculture and plantations, industrial/hotel waste runoff and sand mining. Utilization of the river has harmed the preservation of water resources, as well as increased changes in river morphology due to the destructive power of water caused by, among others, flooding, erosion and sedimentation. The purpose of this research is to determine the amount of bed load transport that occurs at three-point locations on the Code River. This study uses the empirical formula equation with the Meyer-Peter and Müller (MPM) and Frijlink method. Based on the results of research at three points of review locations on the Code River for an analysis of the amount of sediment transport there has been a decrease in the MPM method, the results obtained are from the three points of review locations on the Code River that produce the most sediment transport using the MPM and Frijlink methods, namely the North Ringroad Bridge (Sleman Regency). The amount of sediment transport in a river depends on the flow rate, discharge, cross-sectional area and grain size.
\end{abstract}

Keywords-Code River, Sediment Transport, MPM and Frijlink

\section{INTRODUCTION}

The river is a source of life that functions as a water resource, recreation, irrigation, transportation and so on. In 2010, the enormous eruption at Mt Merapi occurred and vomited a lot of materials. After the eruption, the sediments of cold lava floods then saved in the upstream of Mt Merapi [1]. According to Rahayu [2], there are two dangers of volcanic eruptions, that is primary hazards which directly perceived by residents such as hot clouds, and secondary hazards that are perceived after eruption occurs in the form of cold lava flood that can cause land and settlement damage. According to Ardana and Purwanto [3], cold lava floods as a secondary hazard can occur when the intensity of rainfall high, materials eruption then transported following the river channel.

Code River is a river located in the Province of Yogyakarta Special Region (DIY) and one of the rivers that divide the city of Yogyakarta. Three regency areas are crossed by the Code River, namely: Sleman Regency, Yogyakarta City and Bantul Regency. The majority of people living around the Code River utilize the river flow for their daily needs such as MCK (bathing, washing and toilet), irrigation for agriculture and plantations, industrial / hotel runoff and sand mining. Utilization of rivers in human activities above can lead to a decrease in river water quality and surface erosion which is then carried away by the flow in the form of sediment (sediment transport).

The process of sedimentation is soil carried away by water flow and settles in a place because the discharge flow is slowed or stopped. The discharge flow is one of the factors that influence the sedimentation process, the lower the discharge flow the less sediment transport, while the higher discharge flow, the higher the sediment transport load [4].

According to Sudira [5], the sedimentation process includes the process of erosion, transport, and deposition as well as compaction by sediment itself. According to Kusnan [6], a large volume of sediment depends on the change of the flow velocity, due to changes in the dry season and rainy season, and changes that are influenced by the human activity itself.

Usman [7] explains that the definition of sedimentation is the process of deposition of material transported by water, wind, ice or glaciers. If the capacity of the incoming sediment in a cross-section is equal to the amount coming out, then the river will be called balanced [8].

An unequal sediment supply and transport capacity (a river's ability to transport sediment) could create a river to avulse or significantly change its form by eroding or depositing sediment on the bed or banks [9]. According to Mananoma [10], the increase in water damage in the form of erosion and 
sedimentation is caused by changes in environmental function by the rate of population growth and increasing community activities. Human activities and climate change may alter sand or gravel inputs into alluvial rivers, and therefore graded bedload transport can make severe morphological changes [11].

A large amount of sediment from Merapi Mountain can become a threat for people but also benefit because it can be natural resources such as sand mining for miner [12]. And the amount of sedimentation caused by cold lava floods is feared will bring a big impact in the future along the watershed of Code River.

The upstream of the Code River in the Sleman Regency area crosses the middle of Yogyakarta City and empties into the Bantul Regency area. Currently, the capacity of the Code River from upstream to downstream is very large, one of which is in the central area, namely the City of Yogyakarta and the impact flows in the downstream area (Bantul Regency). Yogyakarta City is one of the central areas which has a population density and industry is increasing every year, which has an impact on morphological changes in the Code River.

Based on the description above, this research needs to be carried out to assess the amount of sediment transport that occurs at three points of the review location, namely the upstream part of the North Ringroad Bridge (Sleman Regency), the middle part of the Sayidan Bridge (Yogyakarta City) and the downstream part of the South Ringroad Bridge. (Bantul Regency) on the Code River.

\section{THEORETICAL FRAMEWORK}

\subsection{Hydrometry}

Hydrometry is a branch of science that studies water measurements or basic data collection for hydrological analysis of rivers [13]. Hydrometry is known as activity on rivers that are carried out to obtain and collect data about rivers. The data obtained includes river flow discharge, water level, sedimentation and other river flow elements.

\subsection{Sediment}

Sediment is a part of the soil that is produced from the erosion process and is carried by the flow of river water from the upstream area and then settles in the downstream [14]. Sedimentation is an event process in which the sediment grains caused by the erosion process are then carried by water flow from high (upstream) to low (downstream) places which can result in silting of riverbeds and changes in elevation so that it will affect river morphology [6].

Sedimentation process may include the process of transport, erosion, compaction, and deposition. The sedimentation process is also complex, starting from falling rainwater which can produce kinetic energy from the initiation process of erosion. Then the land will become a fine particle that can be rolled with the flow, as there are particles that remain on the ground while the other part goes to the river carried away by the flow into sediment transport [15].

\subsection{Sediment Transport}

Sediment transport is a soil particle that results from a sedimentation process which is caused by the erosion of the surface or base of the earth and river cliffs which then move or move continuously following the direction of water flow [15].

Schematically, sediment transport can be described as follows Fig. 1.

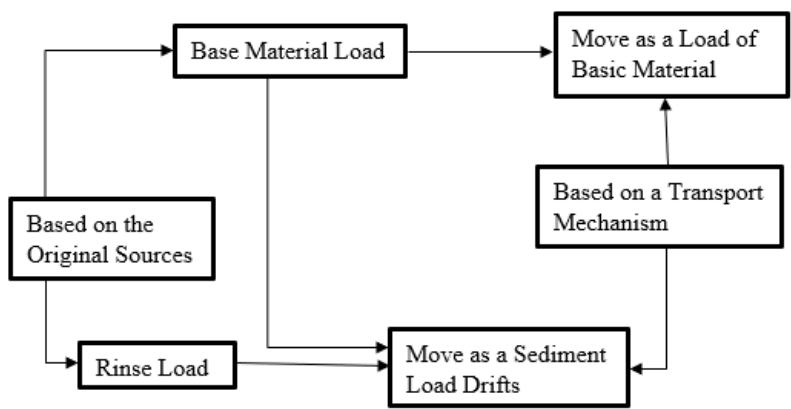

Fig. 1. Schematic of sediment transport [15]

\subsection{Calculation of Sediment Transport Using Empirical Formulas}

\subsubsection{Meyer-Peter and Müller Method}

According to Kironoto [16], the Meyer-Peter and Müller equation states that the total power loss occurs due to the shape of the river bed (shape roughness, dunes/ripple roughness ) and friction with the grains on the river bed (particle/grain roughness).

$$
\begin{gathered}
\gamma_{w} \frac{Q s}{Q}\left(\frac{k s}{k s \prime}\right)^{\frac{3}{2}} S= \\
0.047\left(\gamma_{s}-\gamma_{w}\right) d_{m}+0.25 \frac{\gamma_{w}^{\frac{1}{3}}}{g}\left(T_{b}\right)^{\frac{2}{3}}
\end{gathered}
$$

where:

$\gamma_{w}$

$\frac{Q s}{Q}$

$\left(\frac{k s}{k s \prime}\right)^{\frac{3}{2}}$

$=$ Specific gravity of water $\left(\mathrm{t} / \mathrm{m}^{3}\right)$

$=$ Correction factor

$d m$

= Ripple factor

$=$ Median diameter $\left(d_{50}-d_{60}\right)(\mathrm{mm})$

$=$ Density of sediment transport $\left(\left(\mathrm{t} / \mathrm{m}^{3}\right)\right.$

$=$ Weight of sediment transport (solid) in water $(\mathrm{t} / \mathrm{m} . \mathrm{s})$

\subsubsection{The Frijlink Method}

According to Fauziyah [17], the basis of the Frijlink equation is a formula or equation to find out the Value of the bedload in calculating specific river bed configurations. 


$$
\mathrm{Tb}=\Phi d_{50} \sqrt{g \mu R I}
$$

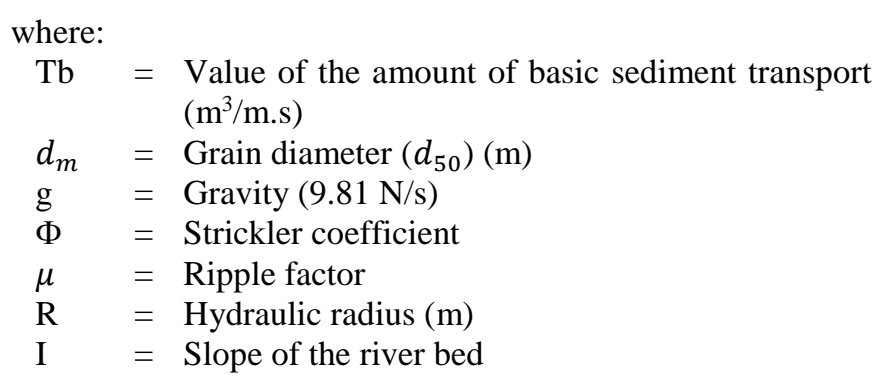

\section{RESEARCH METHODS}

\subsection{Flow Chart}

The research flow chart is the stage or flows from the beginning of the research to get the research results. The research stages can be seen in Fig. 2.

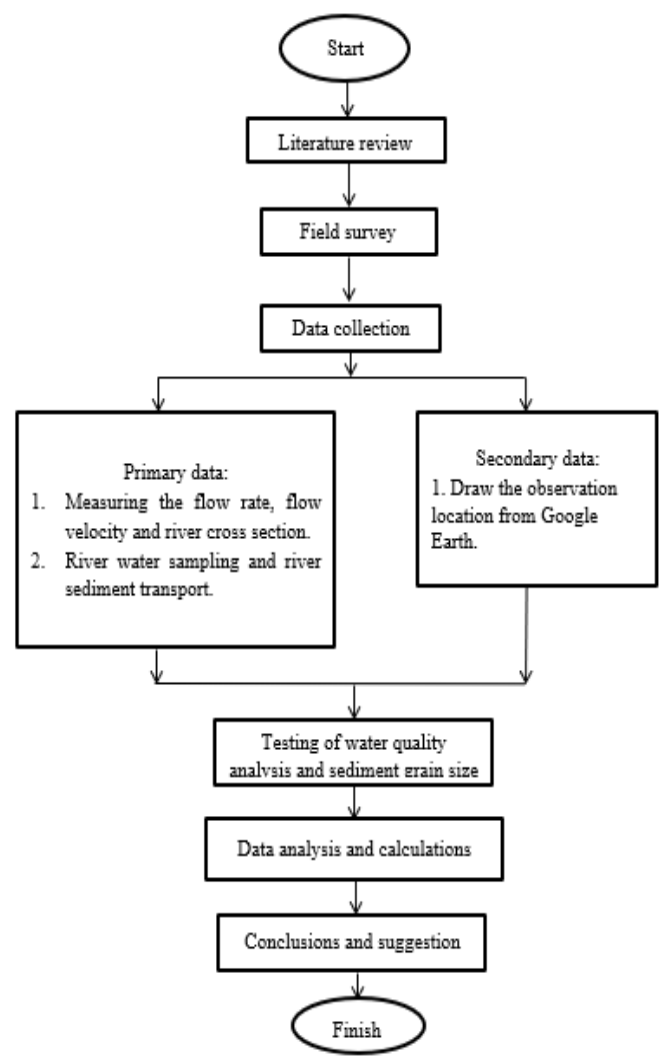

Fig. 2. Flowchart of research stages

\subsection{Determination of Research Location and Time}

The research was conducted with a field survey in the Code River in the city of Yogyakarta. There are three location points in the research sampling, namely the North Ringroad Bridge (Sleman Regency), the Sayidan Bridge (Yogyakarta City) and the South Ringroad Bridge (Bantul Regency). This study was conducted to determine the level of water quality and the amount of sediment transport in three locations of these. The research location can be seen in Fig. 3 .

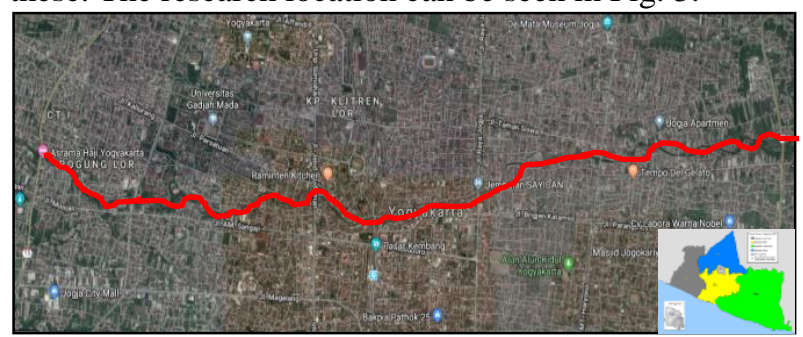

Fig. 3. Location for sampling water and sediment transport

Primary data collection is done by taking data directly in the field and from laboratory results. Meanwhile, secondary data retrieval is done indirectly, such as references from books and the internet. A sampling of water samples was based on SNI 6989.58: 2008 concerning Surface Water Sampling Methods and measurements at three points of review locations on the Code River were carried out for two days, namely on April 24, 2019, and April 262019.

\subsection{Data analysis}

The results of collecting sample data for sediment transport were tested for grain grading at the Geotechnical Laboratory of the S1 Civil Engineering Department, UMY. The calculation analysis to determine the amount of sediment transport using the empirical formula, namely the Meyer-Peter and Müller and Frijlink method.

\section{RESULT AND DISCUSSION}

\subsection{Sediment Transport}

The calculation of sediment transport in this study uses 2 (two) methods, namely Meyer-Peter and Müller and Frijlink. For calculation analysis data at three points of review locations, namely the upstream part of the North Ringroad Bridge (Sleman Regency), the middle part of the Sayidan Bridge (Yogyakarta City) and the downstream part of the South Ringroad Bridge (Bantul Regency) on the Code River can be seen in Table I.

Table I. Data analysis of sediment transport on the Code River

\begin{tabular}{|c|c|c|c|c|}
\hline \multicolumn{5}{|c|}{ Bed Load Transport Calculation Analysis Data } \\
\hline & & $\begin{array}{l}\text { North Ringroad } \\
\text { Bridge }\end{array}$ & $\begin{array}{l}\text { Sayidan } \\
\text { Bridge }\end{array}$ & $\begin{array}{c}\text { South Ringroad } \\
\text { Bridge }\end{array}$ \\
\hline River widtl & & 19.94 & 21.47 & 25.32 \\
\hline Cross-secti & $(\mathrm{H})$ & 3.82 & 3.45 & 4.51 \\
\hline Depth aver & & 0.32 & 0.38 & 0.46 \\
\hline Cross secti & (A) & 6.381 & 8.373 & 11.647 \\
\hline Perimeter $\mathrm{t}$ & ion $(\mathrm{P})$ & 20.58 & 22.25 & 26.64 \\
\hline Flow speed & & 0.51 & 0.37 & 0.27 \\
\hline Flow disch & & 3.254 & 3.098 & 3.145 \\
\hline Specific gr & & 2.67 & 2.66 & 2.66 \\
\hline Slope & & 0.028 & 0.020 & 0.013 \\
\hline Diameter & D50 & 0.55 & 0.8 & 0.55 \\
\hline Sediment & D90 & 1.8 & 2.5 & 1.5 \\
\hline
\end{tabular}




\subsection{Meyer-Peter and Müller Method}

Calculation of sediment transport in the upper reaches of the Code River at the North Ringroad Bridge (Sleman Regency)

\subsubsection{Find the hydraulic radius value}

$$
\mathrm{R}=\frac{\mathrm{A}}{\mathrm{P}}
$$

Where $R$ is hydraulic fingers $(\mathrm{m}), A \quad$ is river flow cross-sectional area $\left(\mathrm{m}^{2}\right)$, and $P$ is wet circumstance river flow (m). Thus,

$$
\mathrm{R}=\frac{6.381}{20.58}=0.310 \mathrm{~m}
$$

\subsubsection{Find the Ripple Factor value}

$$
\mu=\left(\frac{K s}{K s \prime}\right)^{\frac{3}{2}}
$$

Where $\mu$ is ripple factor, Ks is the value of power loss due to the shape of the river bed, Ks' is the value of the power loss resulting from friction with the grain. Thus,

$$
\begin{aligned}
\mathrm{Ks} & =\frac{v}{R b^{\frac{2}{3}} \times I^{\frac{1}{2}}} \\
& =\frac{0.51}{0.310^{\frac{2}{3}} \times 0.030^{\frac{1}{2}}} \\
& =6.428 \mathrm{~m} / \mathrm{s} \\
\mathrm{Ks}^{\prime} & =\frac{26}{D_{90^{\frac{1}{6}}}} \\
& =\frac{26}{0.0015^{\frac{1}{6}}} \\
& =76.847 \mathrm{~m} / \mathrm{s} \\
\mu & =\left(\frac{6.428}{74.847}\right)^{\frac{3}{2}} \\
& =0.024
\end{aligned}
$$

\subsubsection{Calculating the base sediment transport value}

Calculating the base sediment transport

$$
\begin{gathered}
\text { velue } \frac{Q s}{Q}=\frac{R}{h}=\frac{0.310}{0.32}=0.969 \\
\gamma_{w}=\frac{Q s}{Q}\left(\frac{k s}{k s^{\prime}}\right)^{\frac{3}{2}} h \cdot I \\
1 \times 0.969 \times 0.027 \times 0.030= \\
(0.047 \times 1.67 \times 0.00075)+\left(0.25 \times\left(\frac{1}{9.81}\right)^{\frac{1}{3}} \times T_{b}^{\frac{2}{3}}\right) \\
22.33 \times 10^{-5}=5.89 \times 10^{-5}+7981.89 \times 10^{-5} \times T_{b}^{\frac{2}{3}}
\end{gathered}
$$

Sediment transport in the water

$$
T_{b}=9.35 \times 10^{-5} \mathrm{ton} / \mathrm{m} \cdot \mathrm{sec}
$$

Sediment transport by river width

$$
\begin{aligned}
& \text { Total } T_{b}=9.35 \times 10^{-5} \times 19.94=18.644 \times 10^{-4} \text { ton } / \mathrm{sec} \\
& \text { In a day }=24 \times 60 \times 60 \times 18.644 \times 10^{-4}= \\
& 161.084 \mathrm{ton} / \text { day }(\text { in the water })=\frac{161.084}{1.67}= \\
& 96.457 \mathrm{~m}^{3} / \text { day }(\text { solid })
\end{aligned}
$$

Data analysis of sediment transport calculations using the Meyer-Peter and Müller method at three points of review locations on the Code River can be seen in Table II.

Table II. Sediment Transport Calculation Data using the Meyer - Peter Müller Method on the Code River

\begin{tabular}{ccccc}
\hline & \multicolumn{2}{c}{ the Point of Location Observation } & \\
\cline { 2 - 4 } & $\begin{array}{c}\text { North Ringroad } \\
\text { Bridge (Sleman } \\
\text { Regency) }\end{array}$ & $\begin{array}{c}\text { Sayidan Bridge } \\
\text { (Yogyakarta } \\
\text { City) }\end{array}$ & $\begin{array}{c}\text { South Ringroad } \\
\text { Bridge (Bantul } \\
\text { Regency) }\end{array}$ & Unit \\
\hline $\mathrm{R}$ & 0.31 & 0.375 & 0.444 & $\mathrm{~m}$ \\
$\mathrm{Ks}$ & 6.428 & 4.683 & 3.458 & $\mathrm{~m} / \mathrm{sec}$ \\
$\mathrm{Ks}$ & 76.847 & 73.249 & 74.547 & $\mathrm{~m} / \mathrm{sec}$ \\
$\mu$ & 0.024 & 0.016 & 0.01 & $\mathrm{~m}$ \\
$\mathrm{Qs} / \mathrm{Q}$ & 0.969 & 0.964 & 0.965 & $\mathrm{~m}$ \\
$\mathrm{~Tb}$ & 0.0000935 & 0.0000294 & 0.0000151 & ton $/ \mathrm{m} . \mathrm{sec}$ \\
Total of Tb & 0.0006312 & 0.0006312 & 0.0003823 & ton $/ \mathrm{sec}$ \\
$\mathrm{In}$ a day & 161.084 & 54.536 & 33.031 & ton $/$ day \\
& 96.457 & 32.854 & 19.898 & $\mathrm{~m} / \mathrm{day}$ \\
\hline
\end{tabular}

\subsection{Frijlink Method}

Calculation of sediment transport in the upstream part of the North Ringroad Bridge (Sleman Regency)

Finds the hydraulic radius value

$$
\mathrm{R}=0.310 \mathrm{~m}
$$

$$
\begin{gathered}
\mathrm{Ks}=\frac{v}{R b^{\frac{2}{3}} \times I^{\frac{1}{2}}}=\frac{0.51}{0.310^{\frac{2}{3}} \times 0.030^{\frac{1}{2}}}=6.428 \mathrm{~m} / \mathrm{s} \\
\mathrm{Ks}{ }^{\prime}=\frac{26}{D_{90^{\frac{1}{6}}}}=\frac{26}{0.0015^{\frac{1}{6}}}=76.847 \mathrm{~m} / \mathrm{s} \\
\mu=\left(\frac{6.428}{74.847}\right)^{\frac{3}{2}}=0.024
\end{gathered}
$$

\subsubsection{Finding flow intensity}

$$
\Psi=\frac{\triangle d_{50}}{\mu R I}=\frac{1.67 \times 0.00075}{0.024 \times 0.310 \times 0.030}=5.612
$$

The result of the value $\Psi=$ that has been obtained is then entered into the sediment transport graph in the Frijlink method to find the Value of $\Phi$. Then the value $\Phi=1$ is obtained. The graph can be seen in Fig. 4 . 


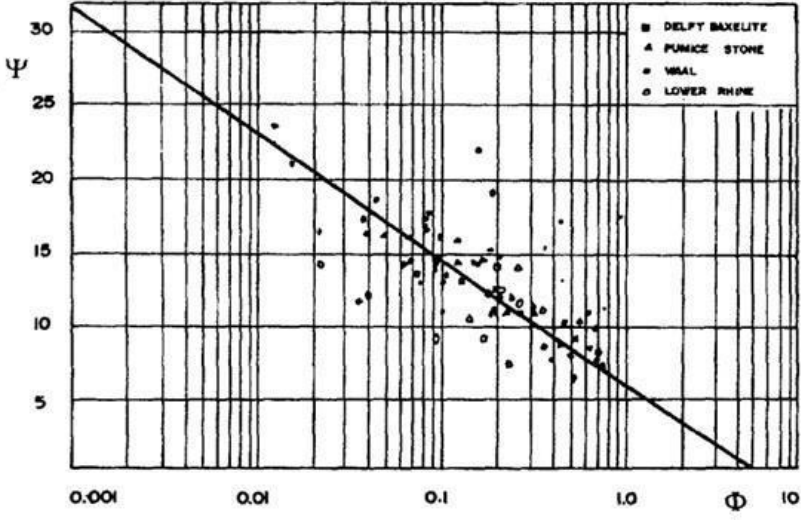

Fig. 4. Graph of sediment transport using the Frijlink method

\subsubsection{Calculate the base sediment transport value}

$$
\begin{gathered}
T_{b}=\phi d_{50} \sqrt{g \mu R I}= \\
1.8 \times 7.5 \times 10^{-4} \times \sqrt{9.81 \times 0.024 \times 0.310 \times 0.024}= \\
3.51 \times 10^{-5} \mathrm{~m}^{3} / \mathrm{m} \cdot \mathrm{sec} \\
\text { Total of } T_{b}=3.51 \times 10^{-5} \times 19.94=6.999 \times 10^{-4} \mathrm{ton} / \mathrm{sec} \\
\text { In a day }=24 \times 60 \times 60 \times 6.999 \times 10^{-4}= \\
60.471 \text { ton } / \text { day }=\frac{60.471}{1.67}=36.2 \mathrm{~m}^{3} / \mathrm{day}
\end{gathered}
$$

Data analysis of sediment transport calculations using the Frijlink method at three points of review locations on the Code River can be seen in Table III.

Table III. Sediment Transport Calculation Data using the Frijlink Method on the Code River

\begin{tabular}{ccccc}
\hline & \multicolumn{3}{c}{ the Point of Location Observation } & \\
\cline { 2 - 4 } & $\begin{array}{c}\text { North Ringroad } \\
\text { Bridge (Sleman } \\
\text { Regency) }\end{array}$ & $\begin{array}{c}\text { Sayidan Bridge } \\
\text { (Yogyakarta } \\
\text { City) }\end{array}$ & $\begin{array}{c}\text { South Ringroad } \\
\text { Bridge (Bantul } \\
\text { Regency) }\end{array}$ & Unit \\
\hline $\mathrm{R}$ & 0.310 & 0.376 & 0.444 & $\mathrm{~m}$ \\
$\mathrm{Ks}$ & 6.428 & 4.683 & 3.458 & $\mathrm{~m} / \mathrm{sec}$ \\
$\mathrm{Ks}$ & 76.847 & 73.249 & 74.547 & $\mathrm{~m} / \mathrm{sec}$ \\
$\mu$ & 0.024 & 0.016 & 0.010 & $\mathrm{~m}$ \\
$\Delta$ & 1.67 & 1.66 & 1.66 & \\
$\psi^{\prime}$ & 5.612 & 9.598 & 8.308 & \\
$\Phi$ & 1 & 0.75 & 0.8 & \\
$\mathrm{~Tb}$ & 0.0000351 & 0.0000221 & 0.000009 & ton $/ \mathrm{m} . \mathrm{sec}$ \\
Total of $\mathrm{Tb}$ & 0.0006999 & 0.0004745 & 0.0002279 & ton $/ \mathrm{sec}$ \\
In a day & 60.471 & 40.997 & 19.691 & ton $/ \mathrm{day}$ \\
& 36.21 & 24.697 & 11.862 & $\mathrm{~m} / \mathrm{day}$ \\
\hline
\end{tabular}

The results of the analysis of sediment transport calculations at three points of review locations, namely the upstream part of the North Ringroad Bridge (Sleman Regency), the middle section at the Sayidan Bridge (Yogyakarta City) and the downstream section at the South Ringroad Bridge (Bantul Regency) on the Code River using 2 (two ) the method in the empirical formula, namely the Meyer - Peter and Müller and Frijlink method, can be seen in Table IV.
Table IV. Comparative analysis of sediment transport data on the Code River

\begin{tabular}{lccc}
\hline \multirow{2}{*}{ the Point of Location Observation } & \multirow{2}{*}{$\begin{array}{c}\text { Flow discharge } \\
(\mathrm{Q})\left(\mathrm{m}^{3} / \mathrm{sec}\right)\end{array}$} & \multicolumn{2}{c}{ Formula $\left(\mathrm{m}^{3} /\right.$ day $)$} \\
\cline { 3 - 4 } & 3.254 & MPM & Frijlink \\
\hline North Ringroad Bridge (Sleman Regency) & 3.098 & 32.853 & 24.210 \\
Sayidan Bridge (Yogyakarta City) & 3.145 & 19.898 & 11.862 \\
\hline South Ringroad Bridge (Bantul Regency) & &
\end{tabular}

From the comparison, the MPM value is greater than the Frijlink Value. One of the factors that caused the difference in yield was the difference in the diameter of the sediment grains. The MPM method uses a D90 sediment diameter, while the Frijlink method uses D50 and D90 sediment diameters. The calculation results obtained at the North Ringroad Bridge (Sleman Regency) are greater than those at the South Ringroad Bridge (Bantul Regency), due to a larger flow rate. The calculation of sediment transport on the Code River at the North Ringroad Bridge (Sleman Regency) using the MPM method yields a result of $96.457 \mathrm{~m}^{3} /$ day, the Sayidan Bridge (Yogyakarta City) of $32.853 \mathrm{~m}^{3} /$ day and the South Ringroad Bridge (Bantul Regency) of $19.898 \mathrm{~m}^{3} /$ day.

While the calculation of sediment transport on the Code River using the Frijlink method on the North Ringroad Bridge (Sleman Regency) gets a result of $36.210 \mathrm{~m}^{3} /$ day, the Sayidan Bridge (Yogyakarta City) is $24.697 \mathrm{~m}^{3} /$ day, and the South Ringroad Bridge (Bantul Regency) is $11.862 \mathrm{~m}^{3} / \mathrm{day}$. It is concluded from the three points of review locations on the Code River that produce the most sediment transport using the MPM and Frijlink methods, namely the North Ringroad Bridge (Sleman Regency).

\section{CONCLUSION}

Based on the results of the study of the calculation of the amount of sediment transport at the three points of the review location, namely the upstream part at the North Ringroad Bridge (Sleman Regency), the middle part at the Sayidan Bridge (Yogyakarta City) and the downstream part at the South Ringroad Bridge (Bantul Regency) on the Code River it can be concluded that From the results of calculation of sediment transport in the Code River in North Ringroad Bridge (Sleman) with MPM method to get the results of 96.457 $\mathrm{m}^{3} /$ day, Bridges Sayidan (Yogyakarta) amounted to $32.853 \mathrm{~m}^{3} /$ day and South Ringroad Bridge (Bantul Regency) amounting to $19.898 \mathrm{~m}^{3} /$ day.

While the calculation of sediment transport on the River Code with methods Frijlink in Bridge Ringroad Utara (Sleman) get a yield of $36.210 \mathrm{~m}^{3} /$ day, Bridges Sayidan (Yogyakarta) amounted to $24.697 \mathrm{~m}^{3} / \mathrm{day}$, and Bridges Ringroad South (Bantul) amounted to $11.862 \mathrm{~m}^{3} /$ day.

It can be concluded from the three points of observation that the Code River produces the most sediment transport using the MPM and Frijlink methods, namely the North Ringroad Bridge (Sleman Regency). The amount of sediment transport in a river depends on the flow rate, discharge, cross-sectional area and grain size. 


\section{ACKNOWLEDGMENT}

Thank you to the Research, Publication, and Community Service Division (LP3M), Universitas Muhammadiyah Yogyakarta for its support of this study, and author colleagues for help.

\section{REFERENCES}

[1] J. Ikhsan, "Studi numerik perubahan elevasi dan tipe gradasi material dasar sungai, [Numerical Study on the Changes of Elevation and Type of Bed Material Gradation]" in Simposium Nasional Teknologi Terapan (SNTT) II, Surakarta, 2014.

[2] Rahayu, D. P. Ariyanto, Komariah, S. Hartati, J. Syamsiyah, \& W. S. Dewi, "Dampak erupsi gunung merapi terhadap lahan dan upaya-upaya pemulihannya, [Effect of Merapi Eruption to the Land and Rehabilition]" Caraka Tani-Jurnal Ilmu Ilmu Pertanian, vol. XXIX, no. 1, pp. 61-72, 2014.

[3] D. M. S. Ardhana, \& T. H. Purwanto, "Penentuan Jalur Evakuasi Dan Dampak Banjir Lahar Dingin Gunung Merapi Magelang, Jawa Tengah, [Evacuation Map and Effect of Debris Flow in Merapi Area, Central Java" Jurnal Bumi Indonesia, vol. 2, no. 2, pp. 149-154, 2013.

[4] A. E. Sembiring, T. Mananoma, F. Halim, \& E. M. Wuisan, "Analisis Sedimentasi di Muara Sungai Panasen, [Analysis of Sedimentation in Estaury of Panasen River]" Jurnal Sipil Statik, vol. 2, no. 3, pp. 148-154, 2014.

[5] I. W. Sudira, T. Mananoma, \& H. Manalip, "Analisis Angkutan Sedimen pada Sungai Mansahan, [Analysis of Sediment Transport in mansahan River]" Jurnal Ilmiah MEDIA ENGINEERING, vol. 3, no. 1, pp. 54-57, 2013.

[6] H. H. Hendar Pangestu, "Analisis Angkutan Sedimen Total pada sungai Dawas Kabupaten Musi Banyuasin," Jurnal Teknik Sipil dan Lingkungan, vol. 1, no. 1, pp. 103-109, 2013.

[7] K. O. Usman, "Analisis Sedimentasi pada Muara Sungai Komering Kota Palembang, [Analysis Sedimentation of Estuary of Komering River in Palembang City] " Jurnal Teknik Sipil dan Lingkungan, vol. 2, no. 2, pp. 209-215, 2014.

[8] I. Saud, "Prediksi Sedimentasi Kali Mas Surabaya, [Estimation of Sedimentation in Mas River,
Surabaya]" Jurnal APLIKASI: Media Informasi \& Komunikasi Aplikasi Teknik Sipil Terkini, vol. 4, no. 1, pp. 20-26, 2008.

[9] E. M. Yager, J. M. Turowski, D. Rickenmann, \& B. W. McArdell, "Sediment supply, grain protrusion, and bedload transport in mountain streams.," Geophysical Research Letters, vol. 39, no. 10, 2012.

[10] T. Mananoma, Sudjarwadi, \& D. Legono, "Prediksi Transpor Sedimen di Sungai Guna Pengendalian Daya Rusak air, [Sediment Transport Estimation in River for Destructive Force of Water]" in Pertemuan Ilmiah Tahunan (PIT) XXII Himpunan Ahli Teknik Hidraulik Indonesia (HATHI), Yogyakarta, 2005.

[11] Z. Li, Z. Cao, H. Liu, \& G. Pender, "Graded and uniform bedload sediment transport in a degrading channel," International Journal of Sediment Research, vol. 31, no. 4, pp. 376-385, 2016.

[12] J. Ikhsan, M. Fujita, \& H. Takebayashi, "Sustainable sand mining management in Merapi area using groundsills.," Disaster Prevention Research Institute Annuals, Kyoto University, vol. 52 B, pp. 647-657, 2009.

[13] Sri Harto Br, Analisis Hidrologi [Hydrology Analysis], Jakarta: Gramedia Pustaka Utama, 1993.

[14] O. Mokonio, T. Mananoma, L. Tanudjaja, \& A. Binilang, "Analisis Sedimentasi di Muara Sungai Saluwangko di Desa Tounelet Kecamatan Kakas Kabupaten Minahasa, [Sedimentation Analysis in Estuary of Saluwangko River in Tounelet Village, Kakas, Minahasa City]" Jurnal Sipil Statik, vol. 1, no. 6, pp. 452-458, 2013.

[15] Soewarno, Hidrologi: Pengukuran dan pengolahan data aliran sungai (hidrometri) [Hydrology; Measurement and Data Analysis of River Flow Hydrometry], Bandung: Penerbit Nova, 1991.

[16] B. A. Kironoto, Hidraulika Transpor Sedimen [ Hydraulics of Sediment Transport], Yogyakarta: Pascasarjana, Universitas Gadjah Mada, 1997.

[17] R. Fauziyah, B. A. Kironoto, \& D. Legono, "Kajian Angkutan Sedimen Di Sungai Pabelan, Kabupaten Magelang, Jawa Tengah, [Sediment Transport in Pabelan River, Magelang, Central Java" Semesta Teknika, vol. 21, no. 1, pp. 53-59, 2018. 